\title{
PPARgamma inhibits hepatocellular carcinoma metastases in vitro and in mice
}

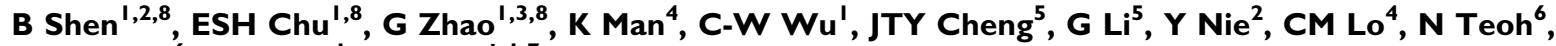 \\ GC Farrell ${ }^{6}$, JJY Sung' and J Yu, ${ }^{*, 1,7}$
}

'Institute of Digestive Disease and Department of Medicine and Therapeutics, Li Ka Shing Institute of Health Sciences, The Chinese University of Hong Kong, Shatin, NT, Hong Kong; '2Department of Gastroenterology and Hepatology, First Municipal People's Hospital of Guangzhou, Guangzhou Medical College, Guangzhou, China; ${ }^{3}$ College of Life Sciences, Inner Mongolia University, Hohhot, Inner Mongolia, China; ${ }^{4}$ Department of Surgery, LKS Faculty of Medicine, The University of Hong Kong, Shatin, NT, Hong Kong; 5 Stem Cells and Regeneration Program, School of Biomedical Sciences and Li Ka Shing Institute of Health Sciences, The Chinese University of Hong Kong, Shatin, NT, Hong Kong; ${ }^{6}$ Department of Gastroenterology and Hepatology, Australian National University Medical School at The Canberra Hospital, Canberra, Australia; 'Department of Medicine and Therapeutics, Prince of Wales Hospital, The Chinese University of Hong Kong, Shatin, Hong Kong

BACKGROUND: We have previously demonstrated that peroxisome proliferator-activated receptor (PPAR $\gamma$ ) activation inhibits hepatocarcinogenesis. We aim to investigate the effect of PPAR $\gamma$ on hepatocellular carcinoma (HCC) metastatic potential and explore its underlying mechanisms.

METHODS: Human HCC cells (MHCC97L, BEL-7404) were infected with adenovirus-expressing PPAR $($ Ad-PPAR $\gamma$ ) or Ad-lacZ and treated with or without PPAR $\gamma$ agonist (rosiglitazone). The effects of PPAR $\gamma$ on cell migration and invasive activity were determined by wound healing assay and Matrigel invasive model in vitro, and in an orthotopic liver tumour metastatic model in mice. RESULTS: Pronounced expression of PPAR $\gamma$ was demonstrated in HCC cells (MHCC97L, BEL-7404) treated with Ad-PPAR $\gamma$, rosiglitazone or Ad-PPAR $\gamma$ plus rosiglitazone, compared with control (Ad-LacZ). Such induction markedly suppressed HCC cell migration. Moreover, the invasiveness of MHCC97L and BEL-7404 cells infected with Ad-PPAR $\gamma$, or treated with rosiglitazone was significantly diminished up to $60 \%$. Combination of Ad-PPAR $\gamma$ and rosiglitazone showed an additive effect. Activation of PPAR $\gamma$ by rosiglitazone significantly reduced the incidence and severity of lung metastasis in an orthotopic HCC mouse model. Key mechanisms underlying the effect of PPAR $\gamma$ in HCC include upregulation of cell adhesion genes, E-cadherin and SYK (spleen tyrosine kinase), extracellular matrix regulator tissue inhibitors of metalloproteinase (TIMP) 3, tumour suppressor gene retinoblastoma I, and downregulation of pro-metastatic genes MMP9 (matrix metallopeptidase 9), MMPI3, HPSE (heparanase), and Hepatocyte growth factor (HGF). Direct transcriptional regulation of TIMP3, MMP9, MMPI3, and HPSE by PPAR $\gamma$ was shown by ChIP-PCR.

CONCLUSION: Peroxisome proliferator-activated receptor-gamma exerts an inhibitory effect on the invasive and metastatic potential of $\mathrm{HCC}$ in vitro and in vivo, and is thus, a target for the prevention and treatment of HCC metastases.

British Journal of Cancer (2012) I 06, I486-1494. doi:I0.1038/bjc.2012.130 www.bjcancer.com

Published online 3 April 2012

(c) 2012 Cancer Research UK

Keywords: PPAR $\gamma$; hepatocellular carcinoma metastasis; heparanase; matrix metallopeptidase; tissue inhibitors of metalloproteinase

Despite significant advances in early detection and therapy, hepatocellular carcinoma (HCC) still remains the third leading cause of cancer-related deaths worldwide (Bosch et al, 2004). The high mortality rate of HCC is mainly attributable to late presentation at advanced stage, where curative surgical resection is no longer feasible or of limited efficacy (Mann et al, 2007). Tumour recurrence in HCC can occur as metastases, whereas more than $90 \%$ of HCC-related deaths are the result of secondary local or distant disease. However, efficacious or curative drug therapy for HCC and its metastases remains elusive.

Peroxisome proliferator-activated receptor-gamma $(\operatorname{PPAR} \gamma)$ is a ligand-activated transcription factor that belongs to the nuclear

\footnotetext{
*Correspondence: Professor J Yu; E-mail: junyu@cuhk.edu.hk.

${ }^{8}$ These authors contributed equally to this work.

Received 6 February 2012; revised 12 March 2012; accepted 14 March 2012; published online 3 April 2012
}

hormone receptor super family; its roles include control of several biological processes related to growth, differentiation, cell cycle, and apoptosis (Koeffler 2003). Activation of PPAR $\gamma$ has been shown to inhibit proliferation in several cancers in vitro and in vivo (Koeffler 2003; Grommes et al, 2004). Our group has recently reported that PPAR $\gamma$ activation by its agonist ( $\mathrm{Yu}$ et al, 2006) or ectopic expression of PPAR $\gamma$ by Ad-PPAR $\gamma$ transfection (Yu et al, 2010) inhibits HCC growth and progression by suppressing cell proliferation, inducing cell apoptosis, and causing cell cycle arrest (Yu et al, 2006, 2010). The PPAR $\gamma$ expression in HCC is significantly reduced in tumour tissues compared with surrounding non-tumourous liver, especially in poorly differentiated tumour than in well-differentiated tumour (Yu et al, 2006). Peroxisome proliferator-activated receptor-gamma also has a role in inhibiting tumour growth and metastatic spread in colon (Takano et al, 2008) and thyroid cancers (Ohta et al, 2001; Chen et al, 2006) as well as lung carcinoma (Panigrahy et al, 2002). However, PPAR's effect on invasive and metastatic potential of HCC has yet to be defined. 
The aim of the present study was to determine the effect and the underlying molecular mechanism of PPAR $\gamma$ on HCC cell migration and invasion using HCC cell lines and formation of distant metastases in vivo in an orthotopic murine liver tumour model.

\section{MATERIALS AND METHODS}

\section{Human HCC cell lines and culture}

The human HCC cell line MHCC97L, stably labelled with luciferase, was a gift from K Man, Department of Surgery, The University of Hong Kong (Man et al, 2010). BEL-7404 was obtained from the Institute of Biochemistry and Cell Biology (SIBS, Shanghai, China) (Chen et al, 1980). Cells were cultured in DMEM (Dulbecco's modified Eagle medium) supplemented with $10 \%$ foetal bovine serum (Invitrogen, Carlsbad, CA, USA) and incubated at $37^{\circ} \mathrm{C}$ and $5 \% \mathrm{CO}_{2}$.

\section{Adenovirus-mediated PPAR $\gamma$ gene transfer}

Recombinant adenovirus expressing the mouse PPAR $\gamma-1$ cDNA (Ad-PPAR $\gamma$ ) or E. coli $\beta$-galactosidase gene (Ad-LacZ, control adenovirus vector) (gift from JK Reddy, Department of Pathology, Feinberg School of Medicine, Northwestern University, Chicago) was propagated, isolated in human embryonic kidney 293 (HEK293) cells, then purified with Adeno-X Maxi Purification Kit (Clontech, Mountain View, CA, USA); the adeno virus with infectious titre range from $1.0 \times 10^{9}$ to $10^{10} \mathrm{pfu}$ (plaque-forming unit) $\mathrm{ml}^{-1}$ was stored at $-80^{\circ} \mathrm{C}$ until use.

\section{RNA extraction, cDNA synthesis, and RT-PCR}

Total RNA was extracted from cell pellets by Trizol (Invitrogen) and reverse transcribed into cDNA using MultiScribe Reverse Transcriptase (Applied Biosystems, Foster city, CA, USA) according to the manufacturer's instructions. The target gene expression was determined by RT-PCR using specific primers of target genes (Table 1). GAPDH was served as an internal control for total cDNA content. Samples were amplified using the ABI Prism 7700 Sequence Detection System (Applied Biosystems).

\section{Tumour cell migration assay}

Wound healing assay was performed for analysis of cell migration in vitro. Briefly, MHCC97L $\left(5 \times 10^{5}\right.$ cells per well $)$ or BEL-7404 $\left(5 \times 10^{5}\right.$ cells per well $)$ cells were seeded in 12-well plates and infected with Ad-LacZ (70 multiplicities of infection, MOI) or Ad-PPAR $\gamma$ (70 MOI), and treated with or without rosiglitazone $(50 \mu \mathrm{M})$ at $37^{\circ} \mathrm{C}$ until $90 \%$ confluent ( $\mathrm{Yu}$ et al, 2010). Sterile tips were used to scratch cell layers, which were subsequently washed with PBS, and cultured with DMEM media and 1\% FBS. Cells were photographed (phase-contrast microscope) at $0,24,36$, and $48 \mathrm{~h}$ after incubation. The distance travelled by cells was measured between the two boundaries of an acellular area and results of treatment groups expressed as a ratio to Ad-Lacz-treated cells. Each experiment was performed in triplicate.

\section{Tumour cells invasion assay}

Matrigel invasion assay (Becton Dickinson, Waltham, MA, USA) was performed as previously described (Yu et al, 2009). MHCC97L and BEL-7404 cells infected with Ad-PPAR $\gamma$ or Ad-LacZ $\left(2.5 \times 10^{4}\right.$ per well) treated with or without rosiglitazone (a selective PPAR $\gamma$ agonist) at $0,24,36$, and $48 \mathrm{~h}$, then harvested and added into the trans-well containing $600 \mu \mathrm{l}$ DMEM media and $10 \%$ FBS in the lower chamber. After $48 \mathrm{~h}$, cells that had invaded through the Matrigel membrane were stained with crystal violet, and counted (four high-power fields, $\times 100$ magnification). Experiments were conducted in triplicate.

\section{Orthotopic murine liver tumour model of distant metastasis}

An orthotopic HCC metastasis mouse model was established using MHCC97L, which has metastatic potential to lung (Man et al, 2010). MHCC97L cells $\left(2 \times 10^{6}\right.$ cells in $0.1 \mathrm{ml}$ PBS $)$ were injected subcutaneously into the left dorsal flank of 4 -week-old male Balb/c nude mice. Subcutaneous tumours were harvested once the subcutaneous tumours reached about $10 \mathrm{~mm}^{3}$ and cut into $1.0 \mathrm{~mm}^{3}$ pieces. One piece of tumour was then implanted into the left liver lobes in a separate group of nude mice (6-week-old) (10 per group) (Man et al, 2010). After tumour implantation, mice were randomly treated with or without rosiglitazone (200 p.p.m. in chow), a dosage was selected base on our previous experiments (Yu et al, 2010). Liver tumour growth and lung metastasis were monitored by Xenogen IVIS-200, an optical in vivo imaging system (Caliper Life Science, Hopkinton, MA, USA) weekly. Mice were euthanised at week 7 after tumour implantation (Man et al, 2010), tumours and lung nodules were analysed histologically. Signal intensity of tumours detected by Xenogen IVIS was expressed as Radiant Efficiency (radiance/illumination power density= $\left.\mathrm{ps}^{-1} \mathrm{~cm}^{-2} \mathrm{sr}^{-1}\right)$. All experimental procedures were approved by the Animal Ethics Committee of the Chinese University of Hong Kong.

\section{cDNA expression array}

Gene expression profiles were analysed by the Human Tumour Metastasis PCR Array according to the protocol (SABiosciences, Frederick, MD, USA). Briefly, total RNA was extracted from MHCC97L cells infection with Ad-PPAR $\gamma$ (70 MOI) or Ad-LacZ (70 MOI) (control) for $48 \mathrm{~h}$. One $\mu \mathrm{g}$ of total RNA was treated and cDNA was prepared using $\mathrm{RT}^{2}$ First Strand Kit (SABiosciences). Pairs of test and control samples were mixed with $\mathrm{RT}^{2}$ qPCR Master mix, distributed to PCR array in 96-well plates, cycling with real-time PCR. Each array contained 84 genes with ascribed functions related to metastasis pathways. Data were analysed using SABiosciences software. Genes with fold-changes more than or less than 1.5 were considered to be of biological significance.

\section{Chromatin immunoprecipitation (ChIP) assay}

Chromatin immunoprecipitation analysis was performed using Red ChIP Kit (Diagenode, Liège, Belgium). After transfection with Ad-PPAR $\gamma$ (70 MOI) or Ad-LacZ (70 MOI) for $48 \mathrm{~h}$, MHCC97L cells were fixed and collected for ChIP assay. DNA-protein complexes were precipitated using specific antibody of PPAR $\gamma$ (Santa Cruz Biotechnology, Santa Cruz, CA, USA). DNA fragments were decross-linked and purified from complexes; immunoprecipitated and input DNA were used as templates for ChIP-PCR.

\section{Characterisation of PPAR $\gamma$-binding region and semi-quantitatation of ChIP-PCR}

To evaluate the direct modulation of transcriptional activity on the promoters of metastasis-related genes by $\operatorname{PPAR} \gamma$, the Genomatix tool, ModelInspector, was used to scan all the known PPAR $\gamma$ binding regions linked to metastasis-related genes. Human promoter regions (size between $2 \mathrm{~kb}$ ) in the Genomatix promoter database were scanned. Matched binding sites were selected with core and matrix similarity of $>0.8$ (http://www.genomatix.de/ online_help/help_matinspector/matinspector_help.html). The predicted PPAR $\gamma$-binding sites on the promoter of target genes were validated by ChIP-PCR (specific primers listed in Table 1). 
Table I Primer sequences for semi-quantitative PCR detection

\begin{tabular}{|c|c|c|}
\hline Gene & Forward primer $\left(5^{\prime}\right.$ to $\left.3^{\prime}\right)$ & Reverse primer $\left(5^{\prime}\right.$ to $\left.3^{\prime}\right)$ \\
\hline MMP9 & TTGACAGCGACAAGAAGTGG & GCCATTCACGTCGTCCTTAT \\
\hline \multicolumn{3}{|l|}{ DNA primers } \\
\hline TIMP3 promoter I & AGGGTCTTTGCACTTGCTGT & ATCCTCGCTGAGAAGTGGAC \\
\hline MMPI 3 promoter 2 & GTTCCTGACCTGAGCAGCAT & TCCCCTGCAGAAGTAAATGG \\
\hline HPSE promoter & GGGTGGTTGATCTCTTCCA & ССТTССТСТСССАTСTAGC \\
\hline
\end{tabular}

\section{Western blot analysis}

Total protein was extracted from cell pellets and protein concentration measured by Bradford assay (Bio-Rad, Hercules, CA, USA). A total of $30 \mathrm{mg}$ of protein was separated by $12 \%$ sodium dodecyl sulphate-polyacrylamide gel electrophoresis, then transferred onto equilibrated polyvinylidene difluoride membrane (Amersham Biosciences, Buckinghamshire, UK). Membranes were probed with primary antibodies for tissue inhibitors of metalloproteinase 3 (TIMP3), heparanase (HPSE), and E-cadherin (Santa Cruz Biotechnology).

\section{Statistical analysis}

Data were presented as means \pm s.d. Multiple group comparisons were analysed by one-way ANOVA after Bonferroni's correction. Non-parametric data between two groups was computed by Chi-square test or Fisher Exact test. The difference for two different groups was determined by Student's $t$ test. A $P$-value of less than 0.05 was considered statistically significant.

\section{RESULTS}

\section{Peroxisome proliferator-activated receptor-gamma suppresses HCC cell migration and invasiveness of MHCC97L and BEL-7404 human HCC cell lines}

The MHCC97L and BEL-7404 cells were infected with Ad-PPAR $\gamma$ or Ad-LacZ (control) in the presence or absence of rosiglitazone for $48 \mathrm{~h}$ and induction of PPAR $\gamma$ was confirmed by Western blot (Figure 1A). Enhanced PPAR $\gamma$ expression by Ad-PPAR $\gamma$ or rosiglitazone, markedly slowed cell migration scratchy 'wound' at edges of MHCC97L and BEL-7404 HCC cells (Figure 1B). Quantitative analyses at $36 \mathrm{~h}$ confirmed a significant reduction in wound closure in Ad-PPAR $\gamma$ or rosiglitazone-treated cells compared with Ad-LacZ-infected control cells (Figure 1C). There appeared to be an additive effect of Ad-PPAR $\gamma$ plus rosilitazone compared with Ad-PPAR $\gamma$ or rosiglitazone only in BEL-7404 cell line (Figure 1C).

To study the effect of PPAR $\gamma$ conferred on the invasiveness of HCC, MHCC97L and BEL-7404 cells were infected with Ad-PPAR $\gamma$, or treated with rosiglitazone using a Matrigel model (Figure2A). In vitro invasively growing HCC cells were significantly impaired by up to $60 \%$ when infected with Ad-PPAR $\gamma$ or primed by rosiglitazone at $48 \mathrm{~h}$ (Figure $2 \mathrm{~B}$ ). Moreover, the combination of $\mathrm{Ad}-\mathrm{PPAR} \gamma$ and rosiglitazone incrementally suppressed cell invasion compared with Ad-PPAR $\gamma$ or rosiglitazone alone (Figure $2 \mathrm{~B}$ ).

\section{Activation of PPAR $\gamma$ by rosiglitazone inhibits HCC metastases to the lung in vivo}

In light of the observed anti-migration and anti-invasion effects of PPAR $\gamma$ on HCC cell lines in vitro, we tested whether activation of
$\operatorname{PPAR} \gamma$ by rosiglitazone could alter metastatic potential of MHCC97L in vivo in an orthotopic metastasis mouse model, where subcutaneously grown tumours derived from MHCC97L cells expressing luciferase were implanted into the livers of nude mice; small successful transplantation of tumours were confirmed by xenogen imaging 2 weeks after surgery (Figure $3 \mathrm{~A}$ ). Mice were randomly treated with rosiglitazone or vehicle for 7 weeks and then re-imaged in vivo. By week 7, 87.5\% (7 out of 8) of the vehicle-treated control mice demonstrated lung metastases after orthotopic implantation. In contrast, only $33 \%$ (3 out of 9) of rosiglitazonetreated animals developed lung metastases $(P<0.05)$ (Figure 3B). The luciferase signals emanating from the lungs originally from the MHCC97L cells expressing luciferase in the rosiglitazone-treated mice were significantly lower than in the vehicle-treated group $\left(1.7 \times 10^{5}\right.$ vs $\left.3.14 \times 10^{6} \mathrm{p} \mathrm{s}^{-1} \mathrm{~cm}^{-2} \mathrm{sr}^{-1}, P<0.05\right)$ (Figure 3C). Subsequent histology confirmed that lung nodules were secondary/ metastatic deposits from liver (Figure 3B). Collectively, these results provide clear evidence that $\operatorname{PPAR} \gamma$ activation inhibits lung metastasis in an orthotopic HCC model in vivo.

\section{Peroxisome proliferator-activated receptor-gamma modulates the expression profiles of metastasis-related genes in MHCC97L cells}

To elucidate the molecular mechanisms underlying the inhibitory effect of PPAR $\gamma$ on HCC cell invasiveness, gene expression profiles in Ad-PPAR $\gamma$-infected MHCC97L were analysed using a human tumour metastasis pathway PCR array. When compared with control Ad-LacZ-infected cells, PPAR $\gamma$ altered downstream targets involved in cell adhesion, extracellular matrix (ECM) proteins, cell growth, and cell motility (Table 2), all of which are critical to the regulation of cancer cell invasiveness and metastasis. Peroxisome proliferator-activated receptor-gamma exerted its anti-metastatic effects by increasing the expression of cell adhesion genes, E-cadherin (5.2-fold), spleen tyrosine kinase (SYK) (1.7-fold), and ECM regulator metallopeptidase inhibitor 3 (TIMP3) (7.2fold), a physiological inhibitor of matrix metallopeptidases (MMPs). The PPAR $\gamma$ also suppressed expression of pro-metastatic genes, such as MMP9 ( -1.7 -fold), MMP13 ( -2.0 -fold), HPSE ( -6.5 -fold), and significantly diminished hepatocyte growth factor (HGF) ( -2.2 -fold), a cellular growth and motility regulator. Further, PPAR $\gamma$-induced retinoblastoma 1 (RB1) expression, a potent tumour suppressor gene by four-fold (Table 2).

To validate these changes on expression profiling, western blot and semi-quantitative RT-PCR were performed on MHCC97L and BEL-7404 cells infected with Ad-PPAR $\gamma$ or Ad-LacZ in the presence or absence of rosiglitazone. Ectopic expression of PPAR $\gamma$ by Ad$\operatorname{PPAR} \gamma$ or activation of $\operatorname{PPAR} \gamma$ by rosiglitazone, increased E-cadherin and TIMP3 protein expression with a concomitant diminution of HPSE in both HCC cell lines (Figure 4A1). Combination of Ad-PPAR $\gamma$ and rosiglitazone exerted an additive effect on the induction of E-cadherin and TIMP3 and suppression 
A

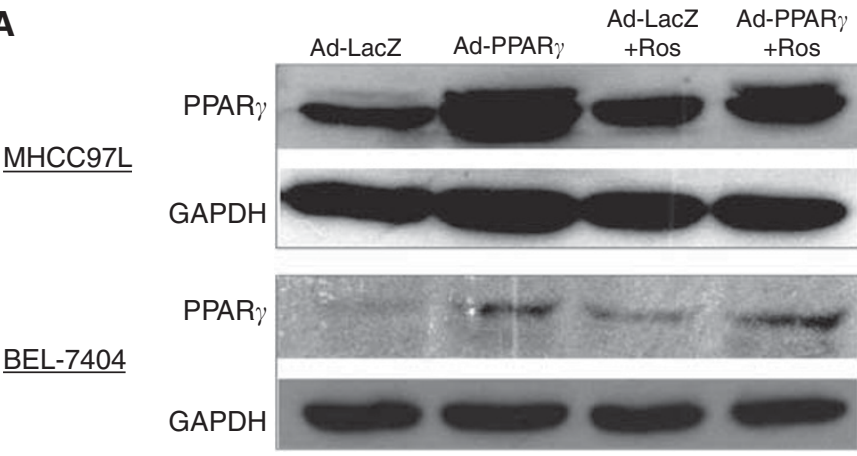

B
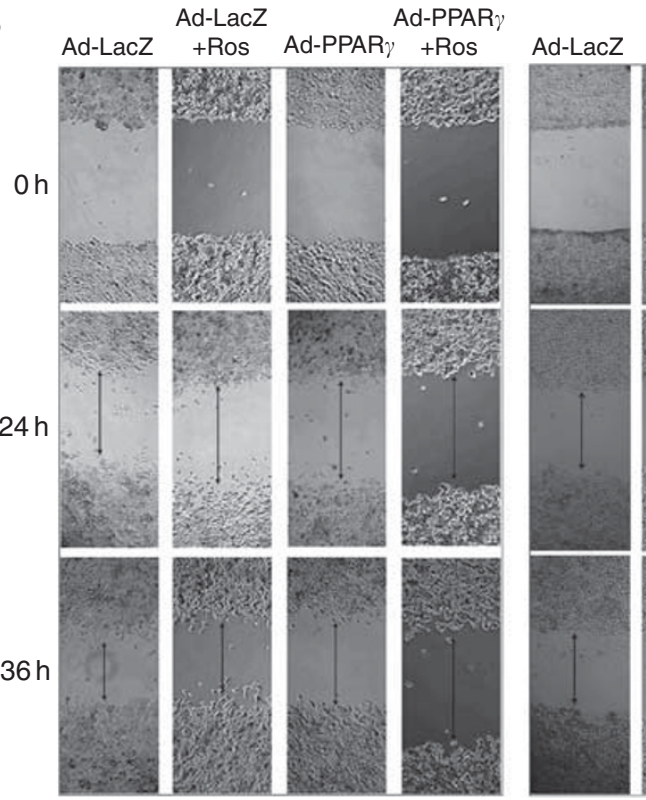

Ad-LacZ Ad-PPAR $\gamma$

$\underline{\mathrm{MHCC} 97 \mathrm{~L}}$
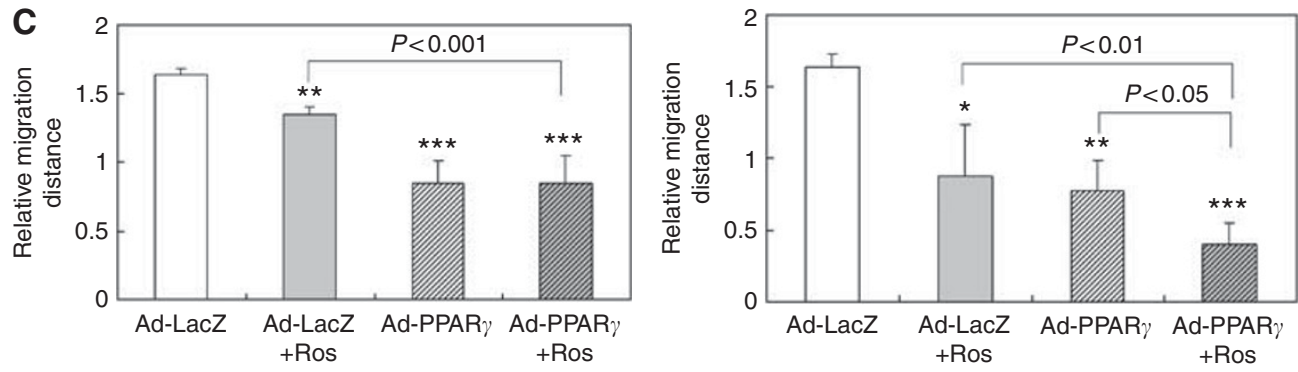

MHCC97L

BEL-7404

Figure I Effect of PPAR $\gamma$ on HCC cells motility by wound healing assay. (A) Pronounced expression of PPAR $\gamma$ protein was confirmed by western blot induced in HCC cells (MHCC97L and BEL-7404) treated with rosiglitazone, Ad-PPAR $\gamma$ or rosiglitazone plus Ad-PPAR $\gamma$. (B) Representative images of the cell motility in MHCC97L and BEL-7404 cells under treatment with Ad-LacZ, Ad-LacZ + rosiglitzaone, Ad-PPAR, or Ad-PPAR $\gamma$ + rosiglitazone at 0, 24, and $36 \mathrm{~h}$, respectively. (C) Quantification of cell motility was made by measuring the distance travelled by the cells between the two boundaries of the acellular area, and the results of the different treatment group were expressed as a ratio to Ad-LacZ-treated cells (control). The experiment was performed for three times in triplicate. The data are expressed as means \pm s.d., $* P<0.05$, ** $P<0.0$ I, **** $P<0.000$ I, compared with the Ad-lac Z.

of HPSE (Figure 4A1). A similar enhanced suppressive effect of the combination of Ad-PPAR $\gamma$ and rosiglitazone was observed on MMP9 and MMP13 mRNA expression by RT-PCR (Figure 4A2).

\section{Direct transcriptional regulation of TIMP3, MMP9, MMP13, and HPSE by PPAR $\gamma$}

To further determine whether PPAR $\gamma$-mediated downstream gene expression changes were associated with direct promoter binding,
PPAR $\gamma$-binding sites in the promoters of identified targets, TIMP3, MMP9, MMP13, and HPSE, were mined using ModelInspector software (Genomatix Software GmbH, Munich, Germany). Chromatin immunoprecipitation assay with $\operatorname{PPAR} \gamma$ antibody was performed in MHCC97L cells followed by PCR confirmation (Figure 4B). By ChIP-PCR assay, PPAR $\gamma$ binds to the promoters of TIMP3, MMP9, MMP13, and HPSE in MHCC97L cells (Figure.4B). These findings suggest that TIMP3, MMP9, MMP13, and HPSE are direct targets of PPAR $\gamma$ in liver cancer cells. 

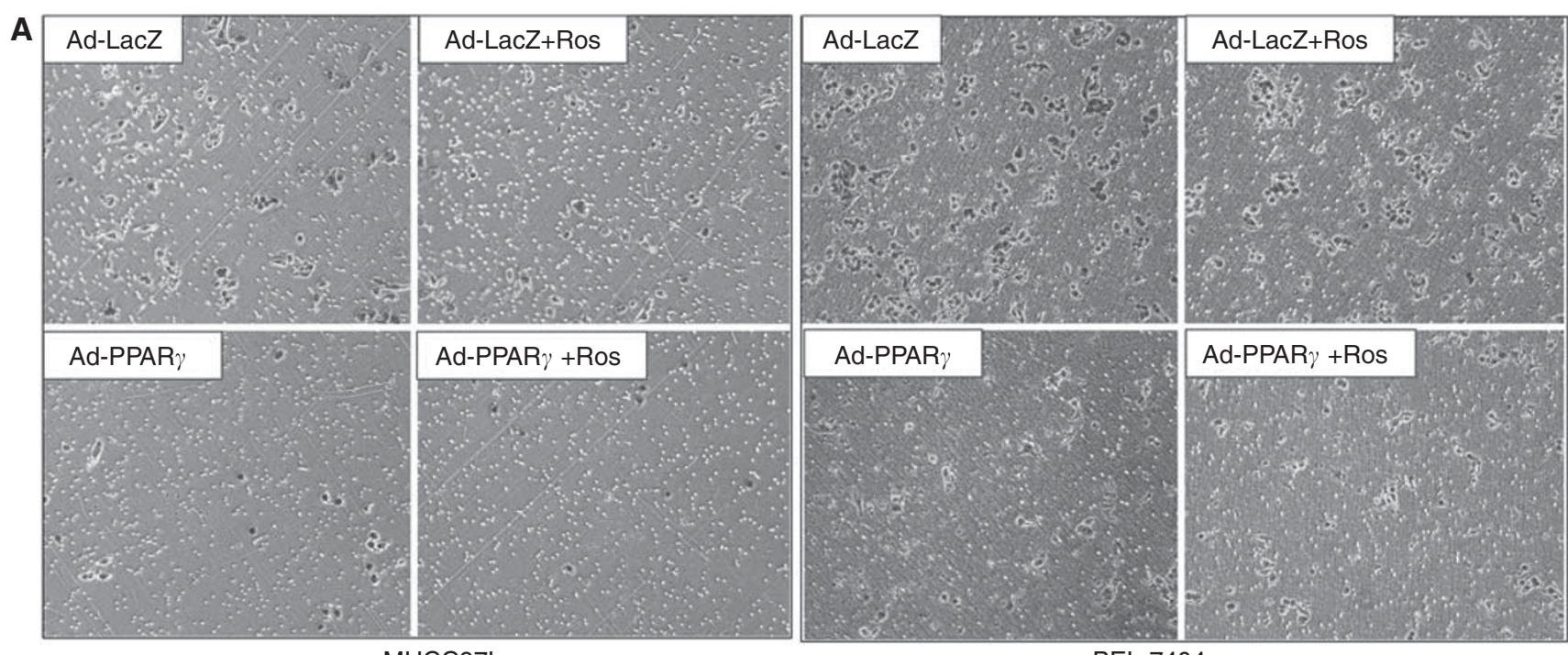

MHCC97L

B

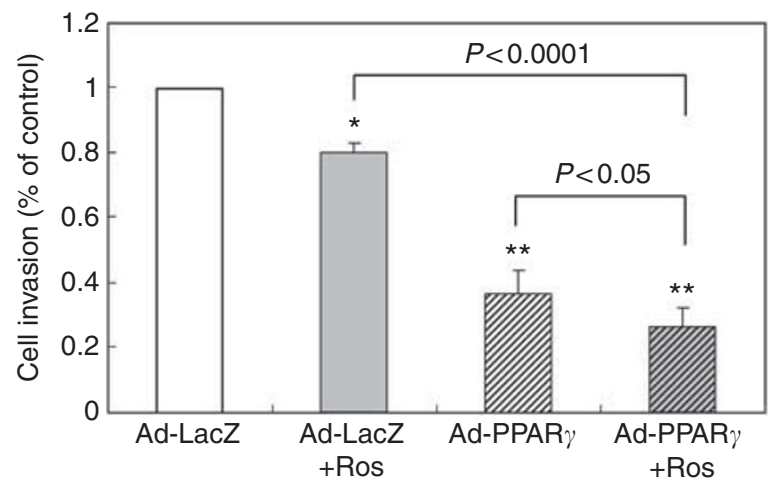

BEL-7404

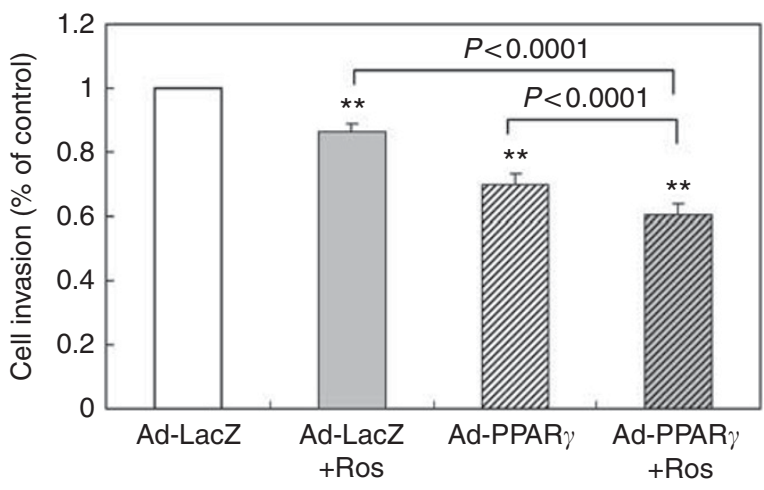

BEL-7404

Figure 2 Effect of PPAR $\gamma$ on HCC cells invasive abilityby Matrigel invasion assay. (A) Representative images of the cell invasive and metastatic ability in MHCC97L and BEL-7404 cells treated with Ad-LacZ, Ad-LacZ + rosiglitzaone, Ad-PPAR $\gamma$, or Ad-PPAR + rosiglitazone at 48 h. (B) Quantification of cell invasion was determined by counting cells that invaded through the Matrigel membrane under a light microscopy $(\times 100)$. The relative cell number ratio of each group was presented by comparing to the Ad-LacZ group (control). The experiment was performed for three times in triplicate. The data are expressed as mean \pm s.d., $* P<0.001$, $* * P<0.000$ I, compared with the Ad-lacZ.

\section{DISCUSSION}

The significance of PPAR $\gamma$ on the process of metastasis is not well studied in contrast to the effect of PPAR $\gamma$ on tumour growth. In this study, we show that ectopic expression of PPAR $\gamma$ by Ad-PPAR or its agonist, rosiglitazone, in two HCC cell lines (MHCC97L, BEL-7404) inhibits metastatic activity in vitro, in particular in wound healing, cell migration, and invasion. Moreover, the combination of Ad-PPAR $\gamma$ and rosiglitazone results in an enhanced anti-metastatic effect. Together, these results indicate that restoration of PPAR $\gamma$ allow for interactions with endogenous or exogenous agonists that activate the anti-metastatic processes associated with PPAR $\gamma$. The role of PPAR $\gamma$ in inhibiting HCC metastases in vitro was further elucidated in an orthotopic HCC xenograft model. In this murine model, activation of PPAR $\gamma$ suppressed HCC lung metastasis in nude mice. Surgical resection or liver transplantation is the curative mainstays of HCC management, however, post-operative recurrence predominantly related to metastasis remains a challenge. Our finding was supported by recent studies, which indicated that activation of PPAR $\gamma$ inhibits metastasis of lung cancer (Reka et al, 2010) and non-small cell lung cancer (Choudhary et al, 2010) in vitro and in vivo. Collectively, our finding that activation of PPAR $\gamma$ by rosiglitazone significantly suppresses metastatic potential could have a beneficial impact on the clinical practice and in adjuvant therapy of HCC after surgical resection and transplantation.

The molecular mechanisms by which $\operatorname{PPAR} \gamma$ exerts its antiinvasive and anti-metastases functions in HCC have not yet been defined. To identify key regulators of $\operatorname{PPAR} \gamma$-mediated antimetastatic effect in HCC, we utilised cDNA microarray and ChIPPCR to study MHCC97L cells infected with Ad-PPAR $\gamma$, genes that were significantly altered in expression levels were then validated by RT-PCR and immunoblotting. We report that the suppression of cell invasion and migration mediated by PPAR $\gamma$ was mediated via downregulation of MMPs (MMP9, MMP13), increased expression of TIMP3 and E-cadherin. Of which, MMP9 and MMP13 are members of extracellular proteinases with key functions in the formation and remodelling of tumour invasion (Khasigov et al, 2003). Matrix metallopeptidase 9 has been described to promote tumour malignant progression, invasion, and metastatic spread by activating tumour growth factor- $\beta$ (TGF- $\beta$ ) (Yu and Stamenkovic, 2000 ). Whereas, MMP13 has a central role in the modulation of other MMPs (Leeman et al, 2002) such as stimulating pro-MMP9 activation (Knäuper et al, 1997). Elevated MMP13 had been shown in various human malignancies including breast cancer, colorectal neoplasms, melanoma, and squamous head and neck tumours, 
A
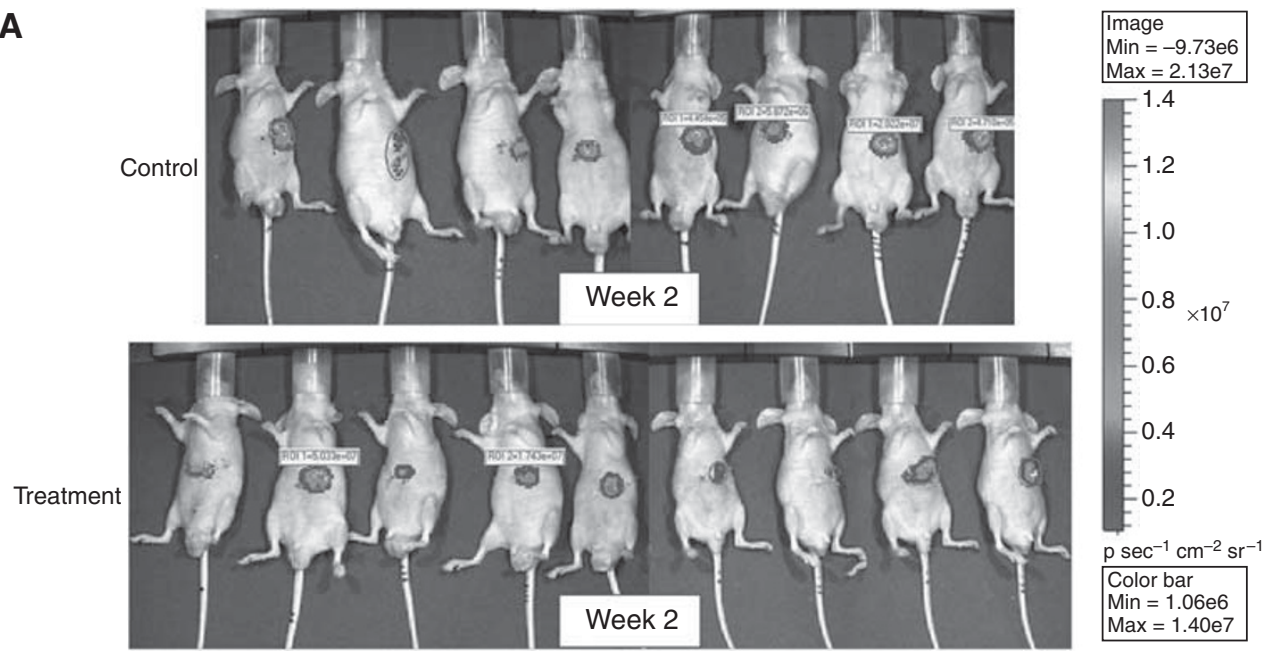

B
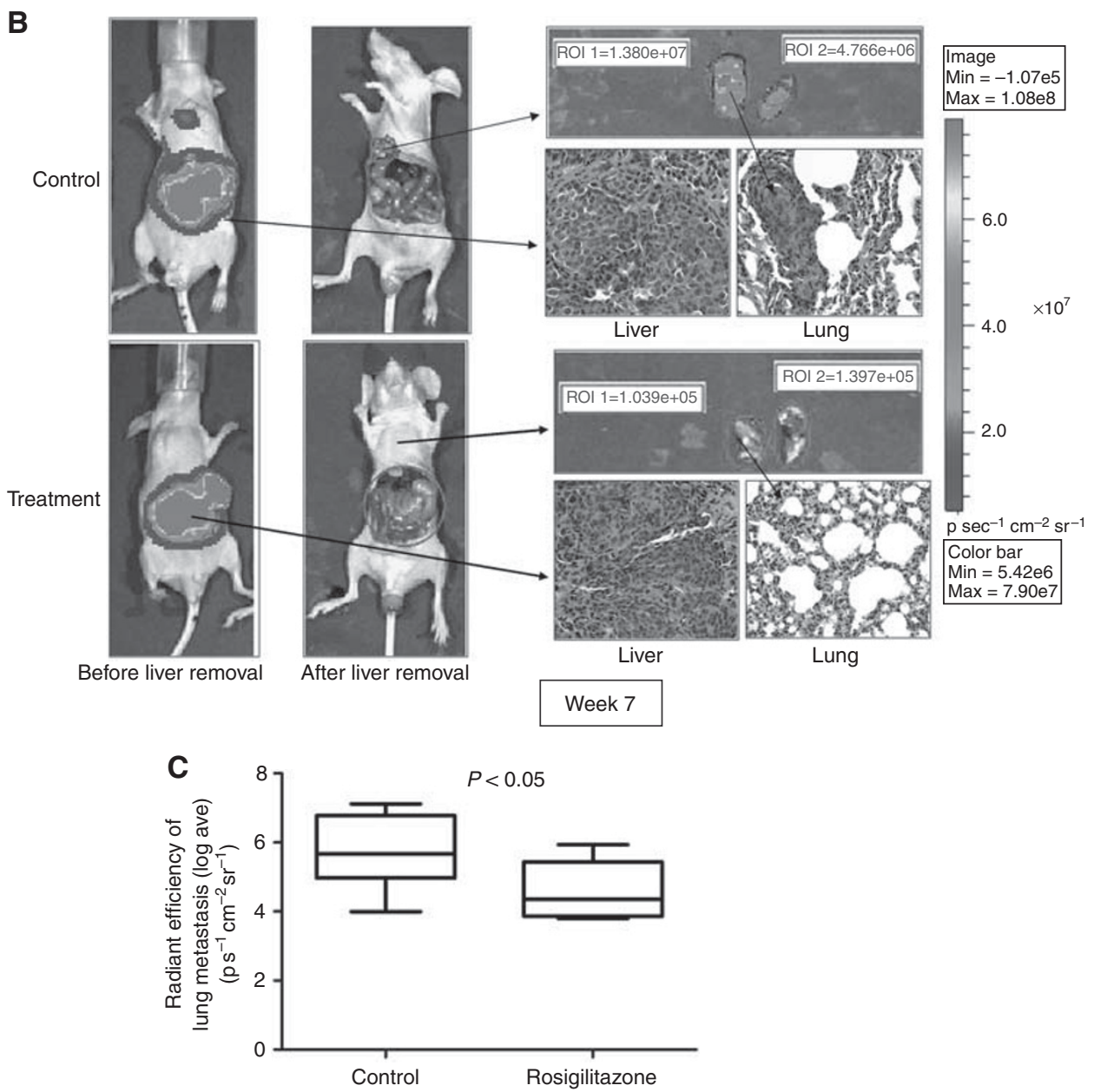

Figure 3 Activation of PPAR $\gamma$ suppressed HCC metastasis in vivo. (A) Tumours derived from the luciferase-labelled MHCC97L cells were successfully implanted orthotopically into the livers of nude mice at 2 weeks. Tumour growth in the mice was monitored by a live imaging system detecting the luciferase signal (unit photons $\mathrm{s}^{-1} \mathrm{~cm}^{-2}$ steradian). (B) Lung metastasis of the HCC mice treated with or without rosiglitazone (200 p.p.m.) at 7 weeks after orthotopic implantation. The liver tumours and lung metastatic nodules were examined by Xenogen IVIS and confirmed histologically. (C) Luciferase signal found in the lungs in the rosiglitazone-treated group was significantly lower than in the vehicle-treated group (log base 10 value is used).

particularly at the invading edge of such cancers; increased MMP13 expression was associated with poor prognosis, tumour aggressiveness, and metastases (Leeman et al, 2002; Luukkaa et al, 2006; Kondratiev et al, 2008; Chang et al, 2009).
Tissue inhibitors of metallo proteinase 3 is an important endogenous inhibitor of MMPs. Upregulation of TIMP3 expression by $\operatorname{PAAR} \gamma$ suggested its suppressive functions in tumour invasion and metastasis via suppressing of MMPs (Bachman et al, 1999; 
Table 2 Effect of PPAR $\gamma$ on its downstream gene expression profiles of cancer metastasis pathways in HCC cell lines

\begin{tabular}{|c|c|c|c|c|}
\hline Full name & Gene & GeneBank & Fold Change (PPAR $\gamma /$ control) & Function \\
\hline E-cadherin & $\mathrm{CDHI}$ & NM_004360 & 5.2 & Cell adhesion \\
\hline Spleen tyrosine kinase & SYK & NM_003177 & 1.7 & Cell adhesion \\
\hline Metallopeptidase inhibitor 3 & TIMP3 & NM_003810 & 7.2 & Extracellular matrix proteins \\
\hline Matrix metallopeptidase 9 & MMP9 & NM_004994 & -1.7 & Extracellular matrix proteins \\
\hline Matrix metallopeptidase 13 & MMPI3 & NM_002427 & -2.0 & Extracellular matrix proteins \\
\hline Heparanase & HPA, HPSE & NM_006665 & -6.5 & Extracellular matrix proteins \\
\hline Hepatocyte growth factor & HGF & NM_000601 & -2.2 & Cell growth and cell motility \\
\hline Retinoblastoma | & RBI & NM_000321 & 4.1 & Cell growth \\
\hline
\end{tabular}

A1

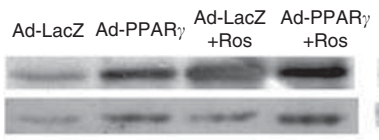

Western blot
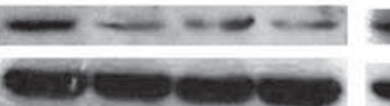

Ad-LacZ Ad-PPARy Ad-LacZ Ad-PPARy

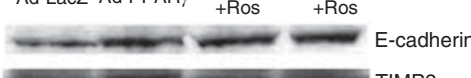

ariMP3
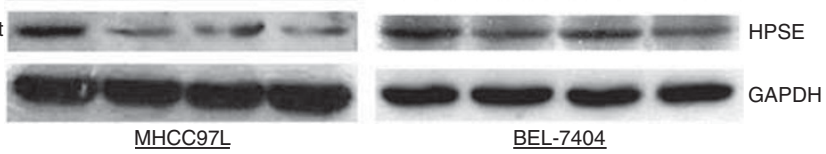

$\bar{\Phi} \quad \square$ Ad-LacZ $\square$ Ad-PPAR $\square$ Ad-LacZ+Ros $\square$ Ad-PPAR $\gamma+\operatorname{Ros}$
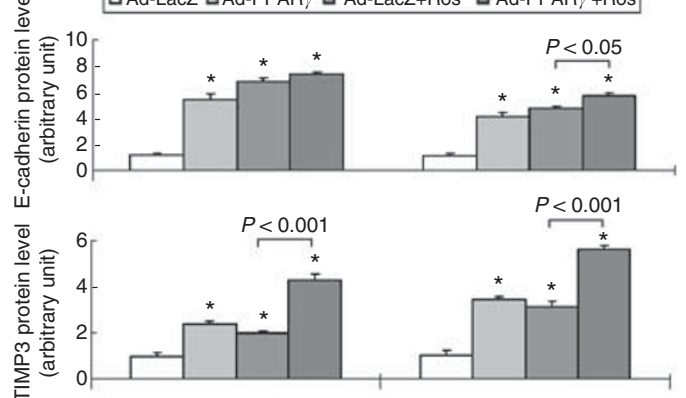

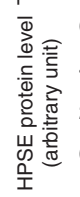

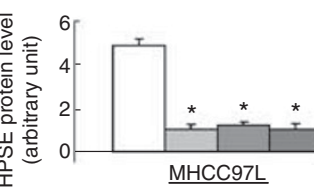

Ad-
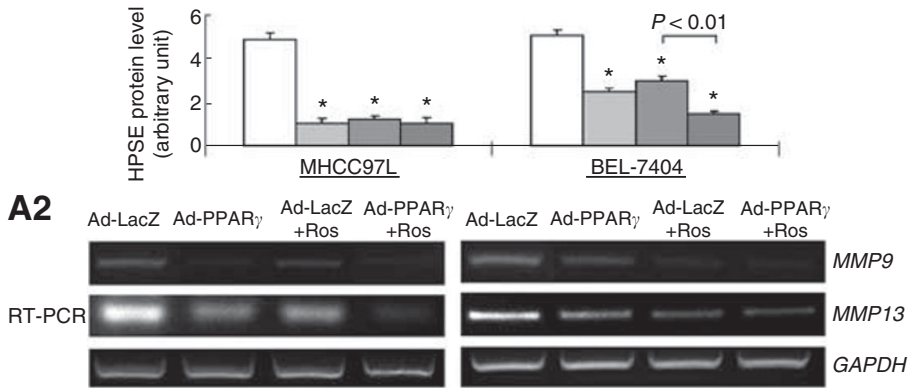

C
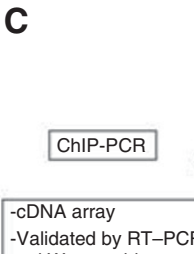
and Western blot
B
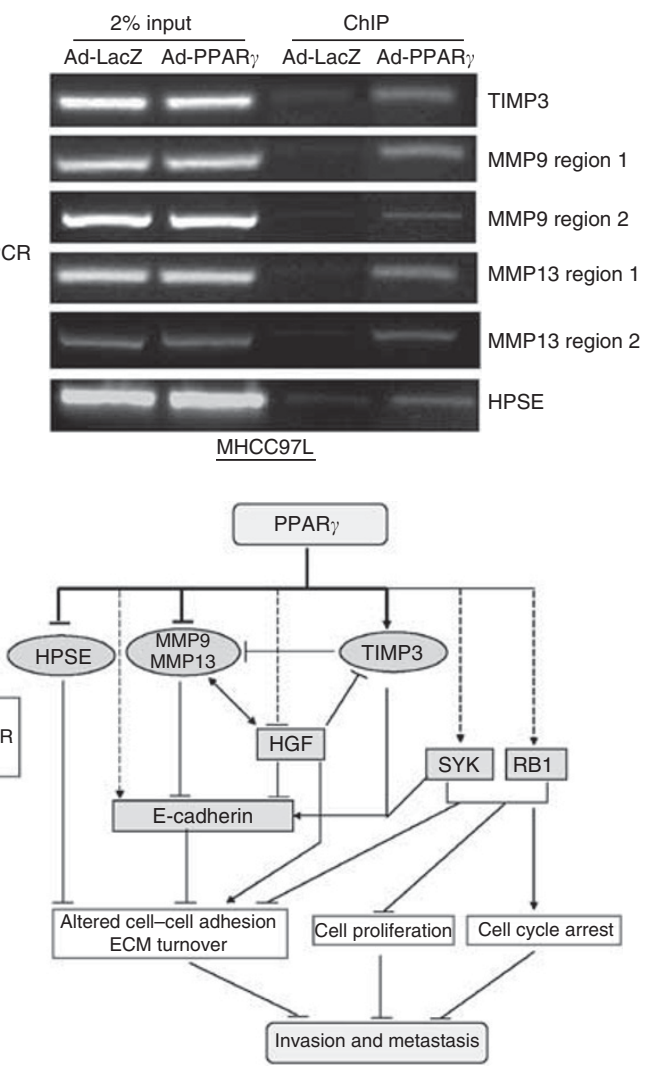

$\square$ Ad-LacZ $\square$ Ad-PPAR $\quad$ 口Ad-LacZ+Ros $\square$ Ad-PPAR $\gamma+$ Ros

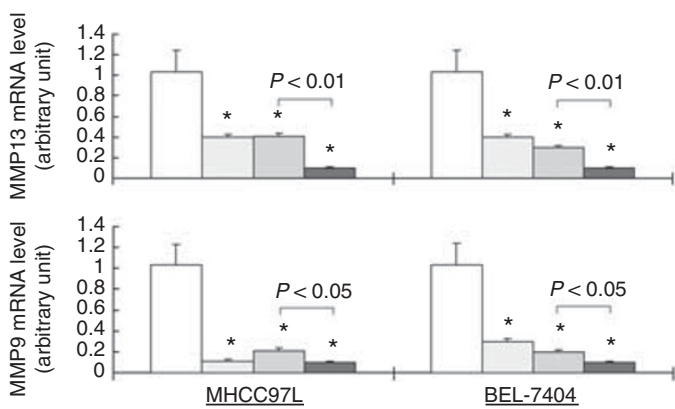

Figure 4. (AI) Western blots were performed to confirm the downstream gene expression regulated by PPAR $\gamma$ in MHCC97L and BEL-7404. GAPDH was used as an internal control. The relevant band densitometry analysis was performed and displayed in the lower panel. (A2) Semi-quantitative RT-PCR and realtime quantitative PCR analyses were performed to validate the candidate genes expression. The data are expressed as means \pm s.d., $* P<0.00 \mathrm{I}$, compared with the Ad-lacZ. (B) Chromatin Immunoprecipitation (ChIP)-qPCR was performed to identify direct targets of PPAR $\gamma$ protein. Input (2\%) represents the genomic DNA. (C) Schematic diagram for the mechanisms of anti-metastasis function of PPAR $\gamma$ deriving from cDNA array, western blot, and ChIP-qPCR. PPAR $\gamma$-mediated suppression of cell invasion and migration was associated with several biological effects: (I) Directly upregulating MMPs (MMP9, MMPI3) and downregulating their inhibitor (TIMP3) by direct binding to the promoter of each targets, and subsequent modulation of cell-cell adhesion molecule E-cadherin, which in turn inhibited the cell-cell adhesion and extracellular matrix (ECM) turnover; (2) Directly inhibiting the transcription of HPSE gene, which contributes to the suppression of ECM turnover and distant metastasis; (3) Downregulation of HGF to suppress the invasive potential; (4) Upregulation of tumour suppressors (RBI and SYK), which protects against tumourigenesis through suppressing ECM turnover, cell proliferation, and causing cell cycle arrest. Blue colour indicates the direct targets, and green colour indicates second targets of PPAR $\gamma$. The colour reproduction of this figure is available at the British Journal of Cancer online. 
Wild et al, 2003). Matrix metallopeptidase 9 and 13 are important mediators in the turnover of ECM and degradation of cell surface molecules such as E-cadherin; they have been described to promote cancer cell migration (Cowden Dahl et al, 2008). Cell-cell adhesion molecule, E-cadherin, is also a key component of epithelial adherent junctions. Loss of E-cadherin expression is a hallmark of epithelial-tomesenchymal transition, a plausible mechanism of driving cancer progression and metastasis (Onder et al, 2008; Makrilia et al, 2009). We demonstrate further that PPAR $\gamma$ inhibits transcription of HPSE by direct binding to its promoter. Upregulation of HPSE has been associated with increased lymph node, as well as distant metastases (Sanderson et al, 2005) and reduced post-operative survival of cancer patients (Sato et al, 2004).

The anti-metastasis function of PPAR $\gamma$ in vitro also appeared to be associated with the downregulation of HGF by cDNA array. HGF is known to act as a multifunctional growth factor and is upregulated in many human cancers including HCC (Ljubimova et al, 1997; Maulik et al, 2002). Hepotocyte growth factor drives epithelial cells to undergo EMT and can downregulate EMTassociated E-cadherin expression in murine liver tumour cells (Ding et al, 2010). Also, HGF has been reported to stimulate MMP9 expression (Mizuno et al, 2005) and increase MMP3 promoter activity in HCC (Ozaki et al, 2003), which can lead to increased cancer cell invasiveness (Reboul et al, 2001; Wang et al, 2007; Lee et al, 2010). Notably, HGF activity may be mediated by MMPs (including MMP9 and MMP13) in the extracellular matrix, and thus induce HCC cells to proliferate and invade (Monvoisin et al, 2002; Mohammed et al, 2005). In contrast, HGF may downmodulate TIMP-3 expression resulting in increased MMP accumulation, hence contributing to the invasiveness and aggressiveness in cancer cells (Castagnino et al, 1998). Thus, the antimetastasis effect of PPAR $\gamma$ in HCC may be in part related to the inhibition of HGF expression (Figure 4C).

\section{REFERENCES}

Bachman KE, Herman JG, Corn PG, Merlo A, Costello JF, Cavenee WK, Baylin SB, Graff JR (1999) Methylation-associated silencing of the tissue inhibitor ofmetalloproteinase-3 gene suggest a suppressor role in kidney, brain, and other human cancers. Cancer Res 59: 798-802

Bailet O, Fenouille N, Abbe P, Robert G, Rocchi S, Gonthier N, Denoyelle C, Ticchioni M, Ortonne JP, Ballotti R, Deckert M, Tartare-Deckert S (2009) Spleen tyrosine kinase functions as a tumor suppressor in melanoma cells by inducing senescence-like growth arrest. Cancer Res 69: 2748-2756

Bosch FX, Ribes J, Díaz M, Cléries R (2004) Primary liver cancer: worldwide incidence and trends. Gastroenterology 127: S5-S16

Castagnino P, Soriano JV, Montesano R, Bottaro DP (1998) Induction of tissue inhibitor of metalloproteinases-3 is a delayed early cellular response to hepatocyte growth factor. Oncogene 17: 481-492

Chang HJ, Yang MJ, Yang YH, Hou MF, Hsueh EJ, Lin SR (2009) MMP13 is potentially a new tumor marker for breast cancer diagnosis. Oncol Rep 22: $1119-1127$

Chen R, Zhu D, Ye X, Shen D, Lu R (1980) Establishment of three human liver carcinoma cell lines and some of their biological characteristics in vitro. Sci Sin 23: 236-247

Chen Y, Wang SM, Wu JC, Huang SH (2006) Effects of PPARgamma agonists on cell survival and focal adhesions in a Chinese thyroid carcinoma cell line. J Cell Biochem 98: 1021-1035

Choudhary R, Li H, Winn RA, Sorenson AL, Weiser-Evans MC, Nemenoff RA (2010) Peroxisome proliferator-activated receptor-gamma inhibits transformed growth of non-small cell lung cancer cells through selective suppression of Snail. Neoplasia 12: 224-234

Coopman PJ, Do MT, Barth M, Bowden ET, Hayes AJ, Basyuk E, Blancato JK, Vezza PR, McLeskey SW, Mangeat PH, Mueller SC (2000) The Syk tyrosine kinase suppresses malignant growth of human breast cancer cells. Nature 406: 742-747

Cowden Dahl KD, Symowicz J, Ning Y, Gutierrez E, Fishman DA, Adley BP, Stack MS, Hudson LG (2008) Matrix metalloproteinase 9 is a mediator of epidermal growth factor-dependent e-cadherin loss in ovarian carcinoma cells. Cancer Res 68: 4606-4613
Tumour suppressor genes, RB1 and SYK, have been reported to be dysfunctional in several cancers where aberrant expression levels appear to correlate with poor prognosis (Bailet et al, 2009; Kouraklis et al, 2009). In contrast, overexpression of RB1 or SYK in several cancer cell types can inhibit tumour growth and reduce metastasis in mouse xenografts (Valente et al, 1996; Coopman et al, 2000). Spleen tyrosine kinase also inhibits the motility of human breast cancer cells (Zhang et al, 2009) and promotes the formation of cell-cell contact through mediation of E-cadherin activity (Larive et al, 2009). In the present study, we describe a near two-fold induction of SYK and impressive upregulation by four-fold of RB1 by PPAR $\gamma$ in keeping with its proposed antimetastatic and -invasive effects.

In conclusion, activation of PPAR $\gamma$ has demonstrated efficacy in suppressing HCC cell migration and invasion in vitro, and in inhibiting distant metastases from liver in an orthotopic HCC model in vivo. Peroxisome proliferator-activated receptor-gamma may provide a potential target for the prevention and treatment of metastatic HCC.

\section{ACKNOWLEDGEMENTS}

The project was supported by Collaborative Research Fund (HKU5/CRF/08) of the Research Grant Council Hong Kong, CUHK Focused Investments Scheme B, National Natural Science Foundation of China 30900665, and National Health and Medical Research Council of Australia Project Grant 418100.

\section{Conflict of interest}

The authors declare no conflict of interest.
Ding W, You H, Dang H, LeBlanc F, Galicia V, Lu SC, Stiles B, Rountree CB (2010) Epithelial-to-mesenchymal transition of murine liver tumor cells promotes invasion. Hepatology 52: 945-953

Grommes C, Landreth G, Heneka M (2004) Antineoplastic effects of peroxisome proliferator-activated receptor gamma agonists. Lancet Oncol 5: 419-429

Khasigov P, Podobed O, Gracheva T, Salbiev K, Grachev S, Berezov T (2003) Role of matrix metalloproteinases and their inhibitors in tumor invasion and metastasis. Biochemistry 68: 711-717

Knäuper V, Smith B, López-Otin C, Murphy G (1997) Activation of progelatinase B (proMMP-9) by active collagenase-3 (MMP-13). Eur J Biochem 248: 369-373

Koeffler HP (2003) Peroxisome proliferator-activated receptor gamma and cancers. Clin Cancer Res 9: 1-9

Kondratiev S, Gnepp DR, Yakirevich E, Sabo E, Annino DJ, Rebeiz E, Laver NV (2008) Expression and prognostic role of MMP2, MMP9, MMP13, and MMP14 matrix metalloproteinases in sinonasal and oral malignant melanomas. Hum Pathol 39: 337-343

Kouraklis G, Katsoulis IE, Theocharis S, Tsourouflis G, Xipolitas N, Glinavou A, Sioka C, Kostakis A (2009) Does the expression of cyclin E, $\mathrm{pRb}$, and p21 correlate with prognosis in gastric adenocarcinoma. Dig Dis Sci 54: 1015-1020

Larive RM, Urbach S, Poncet J, Jouin P, Mascré G, Sahuquet A, Mangeat PH, Coopman PJ, Bettache N (2009) Phosphoproteomic analysis of Syk kinase signaling in human cancer cells reveals its role in cell-cell adhesion. Oncogene 28: 2337-2347

Lee KH, Choi EY, Kim MK, Kim KO, Jang BI, Kim SW, Song SK Kim JR (2010) Inhibition of histone deacetylase activity down-regulates urokinase plasminogen activator and matrix metalloproteinase-9 expression in gastric cancer. Mol Cell Biochem 343: 163-171

Leeman MF, Curran S, Murray GI (2002) The structure, regulation, and function of human matrix metalloproteinase-13. Crit Rev Biochem Mol Biol 37: 149-166 
Ljubimova JY, Petrovic LM, Wilson SE, Geller SA, Demetriou AA (1997) Expression of HGF, its receptor c-met, c-myc, and albumin in cirrhotic and neoplastic human liver tissue. J Histochem Cytochem 45: 79-87

Luukkaa M, Vihinen P, Kronqvist P, Vahlberg T, Pyrhönen S, Kähäri VM, Grénman R (2006) Association between high collagenase-3 expression levels and poor prognosis in patients with head and neck cancer. Head Neck 28: 225-234

Makrilia N, Kollias A, Manolopoulos L, Syrigos K (2009) Cell adhesion molecules: role and clinical significance in cancer. Cancer Invest 27: 1023-1037

Man K, Ng KT, Xu A, Cheng Q, Lo CM, Xiao JW, Sun BS, Lim ZX, Cheung JS, Wu EX, Sun CK, Poon RT, Fan ST (2010) Suppression of liver tumor growth and metastasis by adiponectin in nude mice through inhibition of tumor angiogenesis and downregulation of Rho kinase/IFN-inducible protein 10/matrix metalloproteinase 9 signaling. Clin Cancer Res 6: 967-977

Mann CD, Neal CP, Garcea G, Manson MM, Dennison AR, Berry DP (2007) Prognostic molecular markers in hepatocellular carcinoma: a systematic review. Eur J Cancer 43: 979-992

Maulik G, Shrikhande A, Kijima T, Ma PC, Morrison PT, Salgia R (2002) Role of the hepatocyte growth factor receptor, c-Met, in oncogenesis and potential for therapeutic inhibition. Cytokine Growth Factor Rev 13: 41-59

Mizuno S, Matsumoto K, Li MY, Nakamura T (2005) HGF reduces advancing lung fibrosis in mice: a potential role for MMP-dependent myofibroblast apoptosis. FASEB J 19: 580-582

Mohammed FF, Pennington CJ, Kassiri Z, Rubin JS, Soloway PD, Ruther U, Edwards DR, Khokha R (2005) Metalloproteinase inhibitor TIMP-1 affects hepatocyte cell cycle via HGF activation in murine liver regeneration. Hepatology 41: 857-867

Monvoisin A, Bisson C, Si-Tayeb K, Balabaud C, Desmoulière A, Rosenbaum J (2002) Involvement of matrix metalloproteinase type-3 in hepatocyte growth factor-induced invasion of human hepatocellular carcinoma cells. Int J Cancer 97: 157-162

Ohta K, Endo T, Haraguchi K, Hershman JM, Onaya T (2001) Ligands for peroxisome proliferator-activated receptor inhibit growth and induce apoptosis of human papillary thyroid carcinoma cells. J Clin Endocrinol Metab 86: 2170-2177

Onder TT, Gupta PB, Mani SA, Yang J, Lander ES, Weinberg RA (2008) Loss of E-cadherin promotes metastasis via multiple downstream transcriptional pathways. Cancer Res 68: 3645-3654

Ozaki I, Mizuta T, Zhao G, Zhang H, Yoshimura T, Kawazoe S, Eguchi Y, Yasutake T, Hisatomi A, Sakai T, Yamamoto K (2003) Induction of multiple matrix metalloproteinase genes in human hepatocellular carcinoma by hepatocyte growth factor via a transcription factor Ets-1. Hepatol Res 27: 289-301

Panigrahy D, Singer S, Shen LQ, Butterfield CE, Freedman DA, Chen EJ, Moses MA, Kilroy S, Duensing S, Fletcher C, Fletcher JA, Hlatky L, Hahnfeldt P, Folkman J, Kaipainen A (2002) PPARg ligands inhibit primary tumor growth and metastasis by inhibiting angiogenesis. J Clin Invest 110: 923-932

Reboul P, Pelletier JP, Tardif G, Benderdour M, Ranger P, Bottaro DP, Martel-Pelletier J (2001) Hepatocyte growth factor induction of collagenase 3 production in human osteoarthritic cartilage: involvement of the stress-activated protein kinase/c-Jun N-terminal kinase pathway and a sensitive p38 mitogen-activated protein kinase inhibitor cascade. Arthritis Rheum 44: 73-84
Reka AK, Kurapati H, Narala VR, Bommer G, Chen J, Standiford TJ, Keshamouni VG (2010) Peroxisome proliferator-activated receptor-gamma activation inhibits tumor metastasis by antagonizing Smad3-mediated epithelial-mesenchymal transition. Mol Cancer Ther 9: 3221-3232

Sanderson RD, Yang Y, Kelly T, MacLeod V, Dai Y, Theus A (2005) Enzymatic remodeling of heparan sulfate proteoglycans within the tumor microenvironment: growth regulation and the prospect of new cancer therapies. J Cell Biochem 96: 897-905

Sato T, Yamaguchi A, Goi T, Hirono Y, Takeuchi K, Katayama K, Matsukawa S (2004) Heparanase expression in human colorectal cancer and its relationship to tumor angiogenesis, hematogenous metastasis, and prognosis. J Surg Oncol 87: 174-181

Takano S, Kubota T, Nishibori H, Hasegawa H, Ishii Y, Nitori N, Ochiai H, Okabayashi K, Kitagawa Y, Watanabe M, Kitajima M (2008) Pioglitazone, a ligand for peroxisome proliferator-activated receptorgamma acts as an inhibitor of colon cancer liver metastasis. Anticancer Res 28: 3593-3599

Valente P, Melchiori A, Paggi MG, Masiello L, Ribatti D, Santi L, Takahashi R, Albini A, Noonan DM (1996) RB1 oncosuppressor gene overexpression inhibits tumor progression and induces melanogenesis in metastatic melanoma cells. Oncogene 13: 1169-1178

Wang SW, Pan SL, Peng CY, Huang DY, Tsai AC, Chang YL, Guh JH, Kuo SC, Lee KH, Teng CM (2007) CHM-1 inhibits hepatocyte growth factorinduced invasion of SK-Hep-1 human hepatocellular carcinoma cells by suppressing matrix metalloproteinase-9 expression. Cancer Lett 257: 87-96

Wild A, Ramaswamy A, Langer P, Celik I, Fendrich V, Chaloupka B, Simon B, Bartsch DK (2003) Frequent methylation-associated silencing of the tissue inhibitor of metalloproteinase-3 gene in pancreatic endocrine tumors. J Clin Endocrinol Metab 88: 1367-1373

Yu J, Cheng YY, Tao Q, Cheung KF, Lam CN, Geng H, Tian LW, Wong YP, Tong JH, Ying JM, Jin H, To KF, Chan FK, Sung JJ (2009) Methylation of protocadherin 10, a novel tumor suppressor, is associated with poor prognosis in patients with gastric cancer. Gastroenterology 136: 640-651

Yu J, Qiao L, Zimmermann L, Ebert MP, Zhang H, Lin W, Röcken C, Malfertheiner P, Farrell GC (2006) Troglitazone inhibits tumor growth in hepatocellular carcinoma in vitro and in vivo. Hepatology 43: 134-143

$\mathrm{Yu}$ J, Shen B, Chu ES, Teoh N, Cheung KF, Wu CW, Wang S, Lam CN, Feng $\mathrm{H}$, Zhao J, Cheng AS, To KF, Chan HL, Sung JJ (2010) Inhibitory role of peroxisome proliferator-activated receptor gamma in hepatocarcinogenesis in mice and in vitro. Hepatology 51: 2008-2019

Yu Q, Stamenkovic I (2000) Cell surface-localized matrix metalloproteinase-9 proteolytically activates TGF-beta and promotes tumor invasion and angiogenesis. Genes Dev 14: 163-176

Zhang X, Shrikhande U, Alicie BM, Zhou Q, Geahlen RL (2009) Role of the protein tyrosine kinase Syk in regulating cell-cell adhesion and motility in breast cancer cells. Mol Cancer Res 7: 634-644

(c) (P) This work is licensed under the Creative Commons

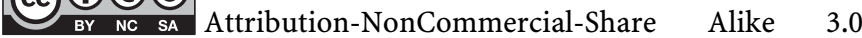
Unported License. To view a copy of this license, visit http:// creativecommons.org/licenses/by-nc-sa/3.0/ 